\title{
Gendered Spheres and Mythic Models in Sappho's Brothers Poem
}

\author{
Leslie Kurke
}

What is striking to me about the newest Sappho, the Brothers Poem, is its complex combination or interpenetration of two levels or spheres. ${ }^{1}$ For here, we find the quotidian — we might even say, a view 'behind the scenes' — progressively infused with mythic models or resonances. We see something of the same interpenetration of the individual with the divine or with epic or mythic resonances in several of Sappho's love poems. Thus Sappho fr. 1 combines an individual's love travails with an epiphany of Aphrodite and distinctive Homeric echoes to expand the poem's significance, while Sappho fr. 16 weaves together the individual's longing for Anactoria with the mythic exemplum of Helen and the vast perspective of the serried ranks of Lydian cavalry and foot soldiers. ${ }^{2}$ Even in Sappho fr. 31, if we accept Jack Winkler's reading, the poem's progressive shift inward and anatomization of the ego's physical symptoms is deftly interwoven with echoes of Odysseus' first encounter with Nausicaa in Odyssey Book $6 .^{3}$ Still, the quality of the quotidian or behind-the-scenes view is not represented in these poems to the same degree; it is perhaps something that distinguishes Sappho's poems about family, politics, and day-to-day life in Mytilene.

To get at these two levels or aspects within the poem, I will consider separately (1) gendered spheres, and then (2) epic or mythic models, along the way in each part paying careful attention to the structure and movement of the song. This division of topics (though to some extent it tracks the development of the poem) is simply a heuristic devise to aid analysis, since what seems distinctive and unusual here is the interpenetration within a single poem of these

1 In addition to the editors and all the contributors to the volume, I would like to thank the following for ongoing conversations, the reading of various drafts, and invaluable input: Kate Gilhuly, Mark Griffith, Barbara Kowalzig, Donald Mastronarde, Kathy McCarthy, Melissa Mueller, Richard Neer, Nelly Oliensis, Alex Purves, Mario Telò, and Naomi Weiss. One of the great pleasures of a brand new Sappho poem is that the work of interpretation is necessarily collaborative and 'choral'.

2 This reading of Sappho fr. 1 follows Marry (1979), Rissman (1983), Winkler (199ob) 166-176.

3 Winkler (1990b) 178-180.

(C) LESLIE KURKE, 2016 | DOI: 10.1163/9789004314832_013

This is an open access chapter distributed under the terms of the Creative Commons Attribution-

Noncommercial 3.o Unported (CC-BY-NC 3.0) License. 
two spheres. I will therefore return to this double quality at the end of my discussion and attempt to knit these two strands together.

\section{Gendered Spheres}

Dirk Obbink notes that based on the layout of the Brothers Poem on P. Sapph. Obbink, we can be certain that we have lost only one, two, or at most three stanzas at the beginning of our song. And if we accept M.L. West's proposal that P. GC fr. 1 represents the remains of the missing column (col. v) between the rest of P. GC (coll. i-iv) and the papyrus that contains the Brothers Poem (col. vi), the extent of the lost opening is narrowed to one to two stanzas (for a total of six to seven stanzas for the Brothers Poem). ${ }^{4}$ What we have starts with the ego reproaching somebody for the wrong kind of speech: 'But you are always chattering about Charaxos coming with a full ship. ${ }^{5} \Theta \rho \nu \lambda \varepsilon^{\prime} \omega$ is a striking word in this context; it appears nowhere else in lyric and seems to be mainly a prose word—even colloquial. ${ }^{6}$ And at least down through Theocritus, it designates negatively-marked speech-babbling, silliness, common talk; speech not to be trusted. ${ }^{7}$ Because of this verb, I am strongly inclined to think that the ego (whom I will henceforth refer to indiscriminately as Sappho) is addressing a female within her own family sphere; I find it almost impossible to believe that Sappho is addressing a man, using this verb to characterize his speech. ${ }^{8}$ At the

4 Obbink (2014b) 34, West (2014) 1-2, 8, Obbink (2015b) 3-5.

5 The infinitive है $2 \theta \eta \eta$, although aorist, must signify a future event; thanks to Donald Mastronarde for discussion and clarification of this point. He explains that the future infinitive is an Attic usage, which only spreads slowly to other dialects, and offers the following parallels for an aorist infinitive used to designate future time: Hom. Od. 20.120-121, Sappho fr. 147, Aesch. Ag. 674-675. See the full discussion of the possibilities in Obbink (2014b) 41-42; cf. West (2014) 8, 'Charaxos' arrival is something hoped for, not something that has already happened; the aorist $\varepsilon^{2} \lambda \theta \eta \nu$ is purely aspectual, not temporal'. See Ferrari (2014) 3 and Lardinois' contribution to this volume, pp. 174-175.

6 Cf. Obbink (2014a) and Lidov, ch. 3, this volume.

7 Cf. Obbink (2014b) 41, Bettenworth (2014) 15, Ferrari (2014) 3. The verb $\theta \rho \nu \lambda \varepsilon \dot{\omega} \omega$ is rare in poetry: see Ar. Eq. 348, Eur. El. 910, fr. 285.1 Kannicht, Anaxippus fr. 1.4 K.-A., Theoc. Id. 2.142; for prose occurrences, see Pl. Phd. 65b (of poets), Isoc. 12.237, Ep. 6.7, Dem. 1.7, 2.6, 19.156, 19.273, 21.16o, Arist. Rh. 1395a10, 1415a3, Hist. an. 62ob11.

8 But cf. Lardinois ([2014] 191 and this volume) who suggests the possibility that Sappho may be addressing her third brother, Erigyius, who was presumably, in the absence of Charaxos, her kurios. Lardinois' suggestion is based on the assumption that the person sending the ego to supplicate Hera must be male and therefore himself not an appropriate suppliant to Hera 
same time, the ego is speaking to someone who has the authority to send her on a religious mission into the public sphere and who is equally concerned with the fate of Charaxos and Larichos - so her mother, older sister, or perhaps sister-in-law. Initially, these considerations led me to the conclusion that the speaker was addressing her mother, and I note that Dirk Obbink and M.L. West have come to the same conclusion. ${ }^{9}$

Indeed, the first two preserved stanzas seem to be all about a contrast in ways of speaking, both the style of speaking and the content of what is said.10 Thus Sappho contrasts the mother's silly chattering with the proper, correct kind of speech to be offered by the ego, which should be supplication and prayer $\left(\lambda i \sigma_{\sigma \sigma \varepsilon \sigma} \alpha \mathrm{\alpha}\right.$, line 10). ${ }^{11}$ At the same time, Sappho implicitly corrects the content

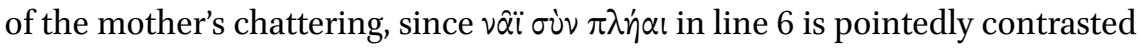
with $\sigma \alpha \dot{\alpha} \alpha \nu \alpha \gamma \gamma \sigma \tau \tau \alpha \nu \hat{\alpha} \alpha$ in lines 11-12 within the ego's projected prayer to Hera.

(as Sappho's mother would be). But we cannot know the familial, cultic, or performance exigencies that dictate this 'sending'; for me, the issue of $\theta \rho \dot{ } \nu \eta \eta \sigma \theta \alpha$ trumps speculation on the gender of the addressee based on $\pi \varepsilon \dot{\varepsilon} \mu \eta \eta \nu$. As a parallel for the derogatory tone of $\theta p \dot{\nu} \lambda \eta \sigma \theta \alpha$ used in address to a brother, Lardinois (this volume) cites the evidence of Hdt.

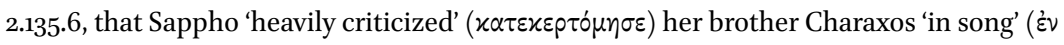
$\mu \varepsilon \dot{\lambda} \varepsilon \varepsilon i)$. But surely Herodotus (and Ovid, Heroides 15.68, 'libertas') comment on Sappho's 'abuse' or '[excessive] freedom' in poems addressed to or concerning Charaxos because these are exceptional, rather than being the norm of the address of a sister to a brother.

Contrast also Stehle's contribution to this volume, pp. 268-269. Stehle contends that the addressee of the poem is Larichos, citing Sappho fr. 96 for a parallel shift from second-person address to third-person naming of Atthis. I find Stehle's argument very difficult, however, since there is nothing in the language of the Brothers Poem to justify or palliate the shift from second-person address to third-person naming. In Sappho 96, this is achieved by explicitly shifting the focalization to the thoughts and longings of the 'other woman' in Lydia; there is nothing comparable to this in the Brothers Poem.

Obbink (2014b) 41-42 favors the idea of Sappho's mother or other family member; cf. West (2014) 8, Ferrari (2014) 4. I will therefore henceforth simply refer to the second-person addressee as 'mother', while leaving open the possibility that it might be some other older female relative or in-law; see below, notes 26,38 . In addition, throughout this essay, I will make no reference to the whole Rhodopis/Doricha tradition that begins with Herodotus 2.135 in relation to the Brothers Poem. This is because I am persuaded (at least for now) by the arguments of Lidov (2002) that this tradition is likely to derive from portraits of Sappho on the Athenian comic stage, rather than from her own poetry. In general, I find the attempt to map Herodotus' relationships onto the Brothers Poem something of a red herring; it seems better simply to read the new poem on its own terms for what can be extracted about the family relationships. 
The emphasis in the latter passage is thus on Charaxos' safe return, rather than on the abundance of cargo he will bring home. ${ }^{12}$ In terms of the structure of the poem, the name of Charaxos frames the first two surviving stanzas with a neat chiasmus: NAME—ship—adj. in lines $5-6$, then adj.-ship—NAME in lines 11-12. This chiastic structure (as Mario Telò points out to me) iconically renders Charaxos' wished-for safe return home within the movement of the poem.

Next, in the only significant enjambment within what we have preserved of the poem, we get part of a line opening stanza three that expresses a reciprocal relationship of safety - 'that Charaxos arrive here leading his ship safe [sTANZA BREAK] And find us safe and sound'. Thereafter, with a strong syntactic break $\left(\tau \dot{\alpha} \delta^{\prime} \dot{\alpha} \lambda \lambda \alpha\right)$ at line 13 , we turn to the second movement of the poem, building up to the sudden appearance of Larichos and the wish for his success at the poem's end. These structural features strongly encourage me to think that perhaps only a single stanza has been lost at the beginning. In that case, we would have a perfect balance - three stanzas about Charaxos, three stanzas about Larichos, with the reciprocal relation of 'our' safety at the exact center of the poem, suturing the two halves together. ${ }^{13}$

On this reading of the opening of the fragment, there is a strict maintenance of gendered spheres within the poem, even if, in a sense, the speaker as poet has the power to mediate between male and female spheres; and between domestic, civic, and divine (as we shall see). Thus, Sappho here talks about the doings of men out in the public world - one brother's engagement in maritime trade, the other's (wished-for) full involvement in the world of the polis ${ }^{14}$ - but all of this is filtered through the intimate domestic sphere of the family and

12 Cf. Nünlist (2014) 13, who likewise notes the contrast between 'full ship' and 'safe ship'. Nünlist also observes that the adjective 'safe' is usually applied to people in Greek; so here, it is a kind of transferred epithet that reinforces the contrast between the two modes of speaking and content of what's said. Mueller (2016) suggests that we might read this contrast meta-poetically — as a generic contrast between an epic/Odyssean voyage (where the goal is to get as much stuff as possible), and a modest 'lyric' voyage.

13 This proposal for the structure of the poem meshes well with Obbink's observation (2014a): 'The remarkable thing is that both texts—-damaged as they are-read almost as though they were complete poems today, partly due to the unique qualities of a poet who cannot have forseen her poetry's survival in fragmentary form'. On this reading, what assists our ability to read the Brothers Fragment as though it were a complete poem is the loss of only a single opening stanza, which included a second-person address.

14 For $\alpha$ un $p$ used of Larichos as a very charged word for full participation in the polis, see Obbink (2014b) 34, 35, 45; cf. West (2014) 9 . 
women's proper religious activity of prayer. ${ }^{15}$ She addresses an older female relative, and wishes for the well-being, safety, and success of her two brothers.

This same maintenance of strictly separated gendered spheres characterizes the correct form of speech and ritual action the ego proposes. After contrasting the mother's empty babbling with what 'Zeus and all the gods know' in the first stanza, Sappho prescribes what the mother ought to do in the second: 'send me and bid me pray to Queen Hera many times that Charaxos arrive here leading his ship safe' (lines 9-12). It is notable that the gender segregation continues in the addressee of the prayer-so in contrast to Zeus and all the gods, mentioned for their omniscience in the first stanza, Sappho should supplicate Hera specifically. ${ }^{16}$ Like many scholars, I am inclined to connect this proposed supplication of Hera with the shrine at ancient Messon (modern Mesa), which seems to be the setting for both Sappho fr. 17 and Alcaeus fr. 129. ${ }^{17}$ Vinciane Pirenne-Delforge and Gabriella Pironti have recently argued that Hera, 'the glorious Aeolian goddess, mother of all' (Alcaeus fr. 129, lines 6-7) was in fact the primary divinity worshipped at Mesa, noting that she alone is addressed in the second person in both Sappho fr. 17 and Alcaeus fr. 129. ${ }^{18}$ I agree with this conclusion, and yet there still seems to be a significant pattern of gender differentiation in aetiological narrative, invocation, and prayer. Thus, in fr. 17 (as Claude Calame has noted), in its aetiological narrative for the foundation of a

15 There is also a distinction here between women's direct discussion of politics and their proper mediation in the public sphere through religion; for this pattern of distinct modes of gendered action in the public sphere, see Foley (1982).

16 Several scholars have noted that Hera is invoked here, as in Sappho fr. 17 , for protection in a sea voyage: thus Lidov (2004) on Sappho fr. 17, Pirenne-Delforge and Pironti (2014) 28 on both poems, and Boedeker's contribution to this volume; cf. de Polignac (1997) for archaeological evidence for this role of Hera at other sites throughout the Aegean and in Southern Italy.

17 On the identification of the shrine in Sappho fr. 17 and Alcaeus frs. 129, 130a, and 13ob with Mesa, see Robert (196ob), Nagy (1993), Nagy (2007b) 213-228, 263, Pirenne-Delforge and Pironti (2014) 27-28. For the connection between that shrine and the prayer to Hera in the Brothers Poem, see Obbink (2014b) 43, (2015b) 7; Lardinois (2014) 192, 194 (suggesting that these two poems may be part of a 'song cycle'); and Bierl (ch. 14), Boedeker, Lardinois, and Nagy in this volume. In support of this identification, Nikolaos Papazarkadas (private conversation) points out that the location of the shrine at Mesa would account for the use of the verb $\pi \dot{\varepsilon} \mu \pi \eta \nu$ in the Brothers Poem line 9, since the ego must be sent on a kind of pilgrimage or theoria outside the city of Mytilene to reach Hera's precinct. For $\pi \dot{\varepsilon} \mu \pi \eta \nu$ as the terminus technicus for sending a pompe, see also the contributions of Bierl (ch. 14) and Nagy to this volume. For the location of the shrine, see fig. 8.1, this volume, p. 199. 
cult of a triad of divinities - Zeus, Hera, and Dionysus-Sappho foregrounds Hera, whereas Alcaeus fr. 129, focusing on the same triad of divinities, significantly begins with Zeus. ${ }^{19}$

At the same time, Pirenne-Delforge and Pironti warn against the too hasty association of 'Queen Hera' and Zeus 'King of Olympus' of the Brothers Poem with the 'Lesbian Triad' of divinities worshipped at Mesa. They propose instead a local, civic representative of the 'glorious Aeolian goddess', perhaps paired with her spouse, and they cite as a striking parallel for the divine couple including a potent Hera a later public inscription from Mytilene. ${ }^{20}$ And yet, here too, the pattern of strict gender segregation in prayers is rigorously maintained. For we find the same gendered opposition between Sappho's intended prayer in the Brothers Poem and the public inscription cited by Pirenne-Delforge and Pironti. This civic inscription from Mytilene, set up probably in the 330 s in the aftermath of war and civil strife, includes a prayer to a string of divinities: ${ }^{21}$

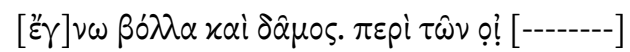

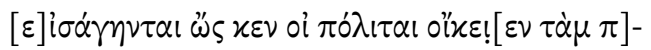

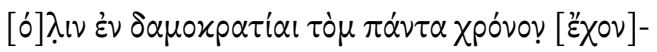

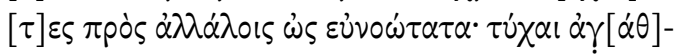

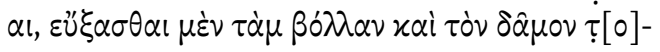

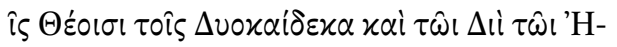

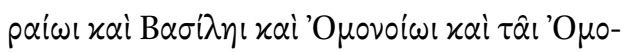

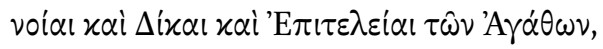

19 C. Calame, 'Greek Myth, Poetry and Pragmatics: Between (French) Structuralism and (Us) Performative Arts' (lecture delivered at Stanford University, Oct. 13, 2012); cf. Boedeker's contribution to this volume. Note also Obbink (2014b) 43, observing that Zeus is 'rarely named in Sappho' in contrast to Alcaeus. Note that the same argument about gender segregation also applies to prayers for safety at sea in the corpus of Sappho and Alcaeus: thus Sappho invokes the Nereids alone (as we now know; fr. 5, line 1) and Hera (Brothers Poem), whereas Alcaeus prays to the Dioscuri (fr. 34). Perhaps this gender segregation is one reason that Sappho's identification/alignment of her two brothers with the Dioscuri (for which I argue below) can only be implicit?

20 Pirenne-Delforge and Pironti (2014) 29: 'Il serait aventureux d'affirmer que les prières à adresser à Héra Basilêa pour le retour de Charaxos devaient l'être dans le sanctuaire de Messa. Contrast Obbink (2015b) 7-9, who is inclined to use the identification of the shrine with Mesa to advocate for Dionysus being the 'helper daimon' of the Brothers Poem line 18 - thus ensuring that all three gods of the 'Lesbian Triad' figure in this poem as well. 
The council and people decided. Concerning the things which the ... have introduced, in order that the citizens might dwell in the city in democracy for all time, as well disposed as possible toward each other: For good fortune, let the council and the people pray to the Twelve Gods and to Zeus Heraios and Basileus and Homonoios, and to Homonoia and Justice and the Fulfillment of Good Things,

Note that this inscription recording a public prayer invokes 'the Twelve Gods' and then Zeus significantly characterized by three epithets-'of Hera', Basileus, and Homonoios - together with a set of transparent personifications, to ratify and endorse civic 'concord' or 'likemindedness.'. ${ }^{22}$ As Pirenne-Delforge and Pironti note, Hera is crucial here as well, ${ }^{23}$ but she is represented only in the form of an adjective built from her name attached to Zeus as the primary object of prayer. Where men in the public sphere invoke 'Zeus of Hera and Basileus', Sappho's song shows us women in the domestic sphere praying exclusively to 'Queen Hera', while gesturing toward the 'King of Olympus' only in the generalizing gnome of the fourth complete stanza.

But within this system of strict gender segregation within the poem, there is a striking crux or tension to which Anja Bettenworth has called our attention. Bettenworth has objected to the assumption that the addressee could be Sappho's mother on the grounds that $\theta \rho \dot{\lambda} \lambda \eta \sigma \theta \alpha$ introduces a markedly disrespectful tone to the ego's response to the $s u$. Bettenworth notes that all other addresses and references to a mother within the Sapphic corpus are distinctly affectionate and respectful, even where we might expect some tension (e.g. frs. 98a, 102). ${ }^{24}$ She contends that $\theta \rho \dot{\lambda} \lambda \eta \sigma \theta \alpha$ could only be addressed to a lower-status figure and therefore suggests that Sappho is instead speaking to a slave member of the household, an aged nurse and confidante akin to Eurycleia in the Odyssey. Indeed, Bettenworth offers some excellent parallels for the combination of sharp remonstrance and deep affection in the speech of a mistress/for-

22 Thus I follow the interpretation of these lines offered by Pirenne-Delforge and Pironti (2014) 30 (vs. that of Rhodes and Osborne [2003] 431). Pirenne-Delforge and Pironti assume that the female divinities named are transparent personifications, not objects of actual cult worship. Note also that Rhodes and Osborne (2003) 425 mistakenly translate $\mathrm{B} \alpha \sigma^{\prime} \lambda \eta \eta$ เ as 'Queen' here.

23 Pirenne-Delforge and Pironti (2014) 30: 'Un tel processus met certes l'accent sur le théonyme, en l'occurrence, l'époux divin, mais cet agencement subtil signifie aussi que Zeus est souverain et maître de la concorde en tant qu'époux d'Héra' (emphasis in original).

24 Bettenworth (2014) 15-16, followed by Nünlist (2014) 13. 
mer charge to a lower-status nurse figure. ${ }^{25}$ But her argument for a nurse figure as addressee to my mind founders on the language and content of the second stanza: 'but you [should] send me and bid me pray many times to Queen Hera that Charaxos come back here leading his ship safe .... As M.L. West has emphasized, only a figure of authority like the mother is in a position to send or dispatch the ego on a religious mission outside the home; I find it hard to imagine that a slave nurse could have the power to 'send' the ego and 'command' or 'bid' her what to pray. ${ }^{26}$ Nonetheless, Bettenworth's point about $\theta \rho \dot{ } \lambda_{\eta} \eta \sigma \alpha \alpha$ is important and should not simply be dismissed; there is a real tension between the colloquial, derogatory tone of this verb addressed to the $s u$ and the implication of authority over the ego encoded in the language and content of the second complete stanza.

Rather than trying to explain away this tension within the poem, I would like to acknowledge it by invoking a model of 'behind the scenes' — or even 'spaceoff'. Kate Gilhuly borrows the latter term from the feminist film critic Teresa de Lauretis to characterize the odd moment early in Plato's Symposium when Eryximachus proposes dismissing the flute-girl: 'Let her play for herself, or, if she wants, for the women within, but let us consort with each other today through

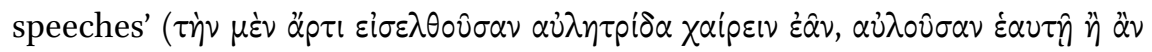

25 See especially $\mathrm{Od}$. 23.11-82 and Herondas Mime 1, cited by Bettenworth (2014) 16-17. In fact, the salient comparandum provided by these passages may instead be the frankness with which women (are imagined to) speak to each other when no men are present; see Mossman (2001) for a reading along these lines of the agon of Clytemnestra and Electra in Euripides' Electra, and see discussion below in the text. Thanks to Melissa Mueller for discussion of these issues, and for the Mossman reference.

Thus West (2014) 8: "It is the family (the "us" of line 9) that pins its hopes on the merchant son's return from overseas with a rich cargo; it is his chattering mother who is counting her chickens before they are hatched; and it is only she who might "send" Sappho on a religious mission, much as Clytemnestra sends Electra in Aesch. Cho. 22 ff. and as Helen sends Hermione in Eur. Or. 107 ff.' Bettenworth (2014) 18 attempts to palliate this problem by assimilating the second complete stanza to the nurse's typical role of advising the mistress, but this does not acknowledge that the specific language of the poem suggests someone with authority over the ego. As a thought experiment, we might imagine how different the tone would be if this stanza instead began, 'but you [should] bid me go and pray to Queen Hera', etc. As an alternative, Bettenworth's arguments about $\theta \rho \dot{ } \nu \eta \sigma \theta \alpha$ being inappropriately disrespectful toward the speaker's mother might encourage us instead to reconstruct the second-person addressee as the speaker's sister-in-law (i.e., Charaxos' wife; see below, note 38). This would then still be an older female with some authority in the household, but one with whom Sappho might imaginably have a somewhat more tense relationship. 


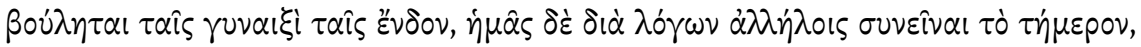
Symp. 176e6-9). As Gilhuly notes, the dismissal of the flute-girl/courtesan from the party effectively banishes the materiality and bodiliness the female slave here represents as the necessary precondition for constituting a space for pure male philosophical discourse. At the same time, the tantalizing reference to 'the women within' conjures an entirely inaccessible 'other' space, like that characterized by de Lauretis as 'a view from elsewhere ... it is the elsewhere of discourse here and now, the blind spots, or the space-off, of its representations. I think of it as spaces in the margins of hegemonic discourses, social spaces carved in the interstices of institutions. ${ }^{27}$ In effect, I suggest, we find moments in Sappho's poetry that offer us a view from the other side of Plato's 'women within' - that deliberately expose that 'space-off' and set it in juxtaposition to the wider public world and public transcript. This is precisely one striking and unusual feature of the Brothers Poem I am trying to elucidate.

A Sapphic parallel will help clarify what I mean, while also furnishing a possible counter-example to Bettenworth's contention that the mother is otherwise consistently treated with the utmost respect-even reverence-in Sappho's poetry. In the same volume of $Z P E$ as Bettenworth's article, M.L. West proposes a partial reconstruction of the poem he thinks preceded the Brothers Poem in the sequence of Sappho Book 1, noting that 'Two poems in which Sappho remonstrates with her mother turn out to have been consecutive.'. ${ }^{28}$ Here is the opening of Sappho fr. 9, heavily reconstructed by M.L. West based on the new readings of P. GC:

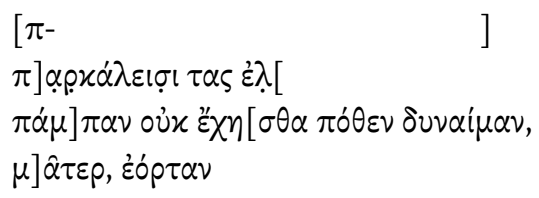

27 De Lauretis (1987) 25, quoted in Gilhuly (2009) 62-64 in discussion of this passage of the Symposium. Cf. Mossman (2001) for the ways in which private female-female speech is marked and characterized in tragedy.

28 West (2014) 2; see 7. According to West's reconstruction, it is possible that this juxtaposition of similarly-themed poems is entirely accidental, simply because both begin with a word that starts with the letter $\pi$. But West (2014) $1 \mathrm{n}$. 3 also allows for the general possibility that similarly-themed poems were deliberately clustered, contravening proper alphabetical order by the first letter of the first word. This might apply to the Brothers Poem itself (whose incipit we have lost); the next poem in sequence (the Kypris Poem) certainly begins with $\pi \hat{\omega}$ s. See also Obbink, ch. 2 , this volume. 


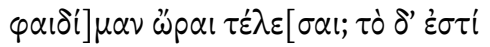

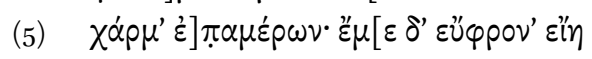

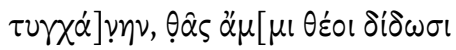
$\varphi \theta o ́ \gamma]$ ov $\alpha$ xov $\sigma \alpha$ l

$\pi \alpha x \tau i \delta] \omega \nu$.

... call upon us ... completely. Mother, do you not have the means with which I might celebrate a fine festival at the due time? That is a joy for [us] mortals who live for the day. As for me, may I ever be cheerful, so long as the gods grant us to hear the sound of harps. ${ }^{29}$

If we accept West's reconstruction, the opening of this poem shares three themes or elements with the Brothers Poem. First, in what I would describe as a similar 'behind-the-scenes' vignette of the preparations for a festival, we have a moment of initial tension between mother and daughter, as the ego addresses a somewhat impatient question to her mother. ${ }^{30}$ Second, that 'behind-thescenes' tussle of mother and daughter is juxtaposed in context with proper religious activity in the public sphere-here in fr. 9 , the song and dance that are essential elements of the festival; in the Brothers Poem, the ego's projected supplication and prayer to Hera. Third, in both poems the segue between these two spheres is accompanied by or finessed through a generalizing gnome or universalizing statement of truth. In fr. 9 this transition is accomplished by

29 Text and translation from West (2014) 7-8. As West observes, lines 8-21 are too fragmentary for reconstruction, though note $\delta^{\prime} \varepsilon^{\prime} \gamma \omega$ in line 16 and perhaps $\left.\mu \varepsilon \lambda \lambda\right]^{\prime} \chi \alpha \nu \gamma \lambda \hat{\omega} \sigma \sigma \alpha[\nu$ in line 17 (suggested by West [2014] 8). The text of West (2014) which I follow diverges from that of Obbink (this volume) at two points: (1) West reads $\dot{\alpha} \mu[$ rather than $\dot{\varepsilon} \mu[$ in line 6 (this is the reading of the 2nd-c. CE P. Oxy. 2289 rather than that of the 3rd-c. CE P. GC); (2) West proposes $\pi \alpha x \tau i \delta] \omega \nu$ as a supplement at line 8 , but Obbink notes '] $\omega$ cannot be read'. (This means that this is not the correct supplement, and that there is less textual evidence to support it than West supposes.)

Thus West (2014) 7: 'We have the impression that Sappho, whose love of festivals is attested in other poems ... is remonstrating with her mother Kleïs (as probably in fr. ga below). The issue is some lack or shortage in connection with a due celebration for which certain persons have issued a call or invitation. Perhaps Kleïs has said she cannot afford an expense that Sappho regards as appropriate. The motif is paralleled in fr. 98, where Sappho herself is the mother, telling her daughter that she cannot buy her a fashionable Lydian $\mu \iota \tau \alpha^{\prime} \nu \alpha$. We might regard this kind of behind-the-scenes moment of preparation for a festival as itself a literary topos particular to partheneia and other women's genres, given Alcman fr. 3.5-10 and Eur. El. 167-212. 


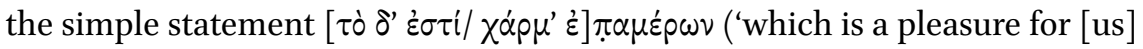
creatures of a day'); in the Brothers Poem by the nautical-themed conclusion of the third stanza, 'For periods of fine weather come straightway from great stormblasts' (lines 15-16).

These parallels in turn allow us to see a further commonality. In fr. 9, the shift from the separate, estranged ego and $s u$ (represented by the verbs oủx $\varepsilon^{\prime} \chi \eta[\sigma \theta \alpha$

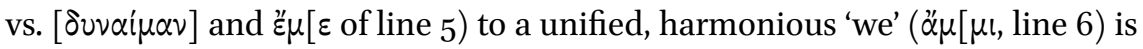
effected through imagined religious activity — mother and daughter together enjoying the festival 'sound [of harps]' for as long as the gods grant them this pleasure. We find the same movement in the Brothers Poem. Here the strongly marked opposition between $s u$ and ego in the first two preserved stanzas $(\theta \rho \dot{\lambda} \lambda \eta \sigma \theta \alpha$ vs. olo $\mu \alpha$ l and $\tilde{\varepsilon} \mu \varepsilon$ in line 9) is transformed via the proper activity and content of prayer-in which the ego basically teaches the $s u$ behind the scenes what to tell her to say-into the unity of 'us ( $\varkappa \alpha \mu_{\mu} \mu$ ', line 13) as the first word of the third complete stanza. Thus, just as in West's reconstruction of the opening lines of fr. 9, the action of prayer-of imagined or projected proper religious speech in the public sphere-works to reconcile and unite mother and daughter.

But in the much better preserved Brothers Poem, we can track this movement further. Here, as a result of the proper form of prayer the ego has taught the $s u$ to teach her, the two continue united in the first-person plural hortatory subjunctive ह่ $\pi \iota \tau \rho o ́ \pi \omega \mu \varepsilon \nu$ of line 14 and in the following generalizing gnome that rounds out this stanza. Given the progression of the Brothers Poem so far, we might be tempted to wonder where exactly the quoted prayer ends. Thus far I have assumed (as I think most scholars do) that the instructed prayer is com-

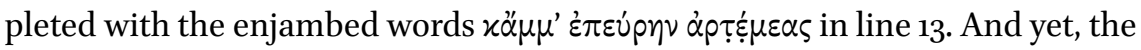
words of the prayer the ego teaches the $s u$ to teach her could imaginably extend to the end of the poem, moving through the resigned hortatory subjunctive of line 14 and the gnomic wisdom of lines $15^{-20}$ to return to 'us' and a final wish for our release from 'great heavinesses of spirit' in the poem's last stanza. ${ }^{31}$

On this reading, the poem's language morphs imperceptibly from behindthe-scenes verbal tussling to public performative utterance, which is effica-

31 For parallels for the shift from accusative + infinitive to direct discourse within quoted utterance, see Sappho's Tithonus Poem, lines 9-12-at least on one construal of this passage. For this interpretation (which reads the final lines of the poem as entirely

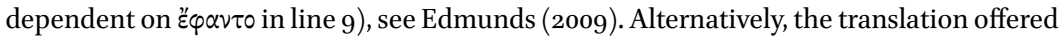
in Obbink (2009) 15 assumes a break between $\varepsilon^{\prime \prime} \varphi \alpha \nu \tau 0+$ acc. and infinitive and the final $\alpha \lambda \lambda^{\prime}$ $\alpha \hat{\tau} \tau 0 \nu$ ن̈ $\mu \omega \varsigma$ clause that follows. Note an analogous shift in Sappho fr. 1 from repeated oै $\tau \tau$ เ clauses as object of Aphrodite's verb of questioning to direct questions and direct speech starting at line 18 . 
cious in at least a couple of different senses. As prayer, the poem deftly reaches out through Hera to Zeus as 'King of Olympus', without ever invoking the high god directly. At another level, the language of the poem as imagined prayer itself accomplishes the reconciliation of ego and $s u$ as 'we' it appears merely innocently to represent. And here it is noteworthy that the poem's last stanza is entirely framed by first-person plurals, $\chi \dot{\alpha} \mu \mu \varepsilon \varsigma$ (line 21) and $\lambda \dot{v} \theta \varepsilon \mu \varepsilon \varepsilon$ (line 24), as ego and su are fully united in family solidarity and hope for Larichos' saving intervention. In other terms, if we read the quoted prayer as extending through the whole poem, we must imagine its words doubled and voiced simultaneously by ego and $s u$, the two voices fusing as a kind of chorus, even as the language of prayer shimmers between and imperceptibly merges private and public spheres. ${ }^{32}$

\section{Mythic Models}

At this point let me return to the enjambed line at the center of the poem-

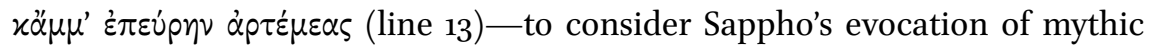
models for her own family drama. As many scholars have noted, the wish for Charaxos' safe return from a sea voyage in the first two preserved stanzas inevitably conjures up general associations with the Odyssey. ${ }^{33}$ But it is this phrase in line 13 that pinpoints a specific Odyssean intertext. To begin with,

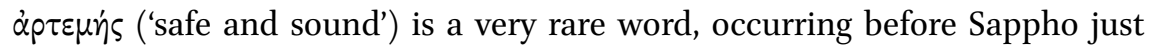
three times in Homer-in a line repeated twice in the Iliad and at a significant moment in the Odyssey (Od. 13.38-46). ${ }^{34}$ Here at the beginning of Odyssey

32 In relation to ego and su fused as a kind of harmonious chorus at the end, I note Melissa

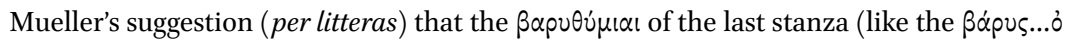

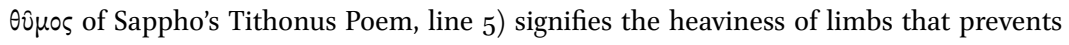
full participation in choral dance. For this specific significance of $\theta \hat{\imath} \mu \circ \varsigma$, see Lidov (2009) 95-96; for more on the 'virtual chorality' of the Tithonus Poem, see Bierl (2016). Thus in our song, if Larichos 'raise his head and become a man', mother and daughter both might return to the proper activities of choral dance and festival celebration.

33 Thus Obbink (2014a); cf. Nünlist (2014), West (2014) 9, Whitmarsh [Online], as well as Boedeker and Stehle in this volume.

34 See Il. $5.515=7.308$. As Mario Telò points out to me (per litteras), Il. 5.515 may also furnish a significant intertext: 'since in this passage it's a specific god, Ares, who, complying with Apollo's request, makes Aeneas safe ( $\dot{\alpha} \rho \tau \varepsilon \mu \eta \dot{\zeta})$. Ares saves Aeneas, but also instills $\mu \varepsilon$ vo in

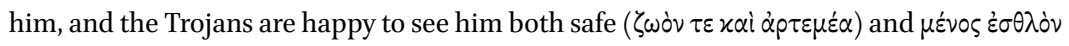

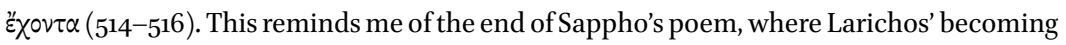
a "man" ( $\alpha \eta \eta p)$ is seen as a source of relief and joy ... for Sappho and the family'. See also 
Book 13, Odysseus addresses his last words to his Phaeacian host, Alcinous, before finally boarding the magical ship that will provide him safe passage home:

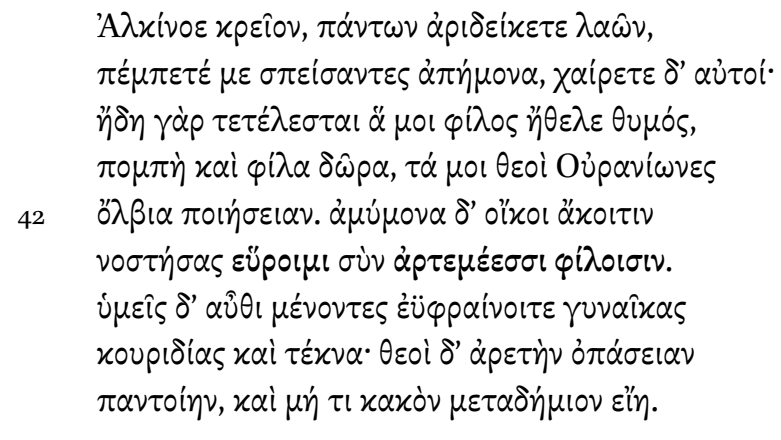

Lord Alcinous, pre-eminent among all people, having poured libation send me on my way without grief, and you yourselves fare well. For already all my dear heart wished for has been fulfilled for me-escort and welcome gifts - which may the Ouranian gods cause to prosper for me. And having returned home, may I find a blameless wife together with my near-and-dear ones safe and sound. But you in turn, remaining behind, may you cheer your wedded wives and children; and may the gods bestow every sort of success on you, and may there be no evil among the people.

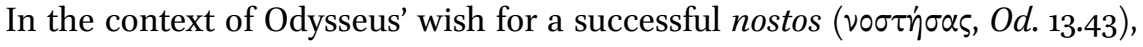
we find the collocation of a form of the verb eipi $\sigma x \omega$ with the rare adjective

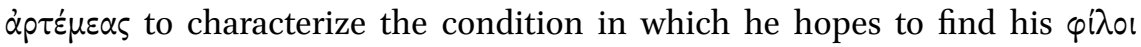
at home. ${ }^{35}$ This connection, in turn, invites us to notice a whole sequence of suggestive echoes of this passage in Sappho's Brothers Poem. There is of course the theme of nostos, but also of $\pi \circ \mu \pi \eta$-in Sappho's song, significantly transferred from the man en route to the action of the women at home $(\pi \varepsilon \dot{\varepsilon} \mu \pi \eta \nu$,

Stehle's contribution to this volume for extended discussion of the meaning of $\dot{\alpha} \tau \varepsilon \mu \eta \dot{\zeta} \varsigma$ with a focus on these Iliad passages, and Boedeker's contribution to this volume.

Nünlist (2014) 13-14 also notes this likely intertextual echo of Odyssey 13 in line 13 of Sappho's poem, pointing to the shared themes of nostos, finding, and 'those at home safe and sound'; cf. Ferrari (2014) 3. Nünlist, however, does not pursue the further implications of this Odyssean intertext for a reading of the Brothers Poem, but see the perceptive comments of Prauscello apud Ferrari (2014) 3 n. 6. 
line 9) $\cdot{ }^{36}$ In addition, there is Odysseus' acknowledgment that ultimately the gods alone can confer olbos and success (Od.13.41-42, 45-46; cf. Brothers Poem lines 10-11, 17-20), and his wishes for the reciprocal happiness and safety of those left at home. To be sure, in the Odyssean case, the families at home are doubled, since Odysseus is at this point in transit, suspended between his own family ideally 'safe and sound' on Ithaca and his wish for the future happiness and blessing of Alcinous and his women and children left behind in Phaeacia. We might say that Sappho's poem gathers in and appropriates all Odysseus' good wishes for the family Charaxos has left behind in Mytilene. Finally, it is suggestive that Odysseus completes the list of blessings he wishes for Alcinous and Co. by expanding to the civic level: 'And may there be no evil

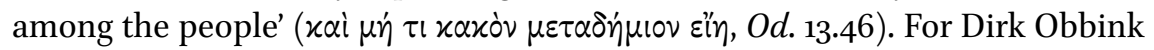
has detected precisely the same shift in Sappho's closing prayer that Larichos

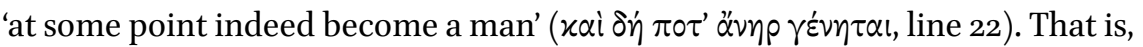
Obbink interprets this as a wish for Larichos' full engagement and participation in civic affairs, rather than merely a prayer that he survive to adulthood. ${ }^{37}$ Thus this phrase at the center of our poem invites us to hear a whole set of Odyssean echoes, as well as subtle variations on Odyssean themes. As such, it fully justifies the scholarly impulse to read the newest Sappho in the framework of the Odyssey myth, casting Charaxos as a kind of Odysseus figure and the younger brother Larichos as 'a potential Telemachos.'38

36 Cf. Mueller (2016), who emphasizes the ways in which Sappho's song 're-centers' the Odyssey narrative by focusing on the efficacious activity of the women at home.

37 Thus Obbink (2014b) 34, 35, 45; cf. West (2014) 9. For a similar interpretation, with a more iambic inflection, see Martin in this volume.

38 Quotation from Obbink (2014a). Cf. West (2014) 9: 'Her younger brother Larichos, who might be expected to take some initiative, remains inert and submissive, rather like Telemachos at the start of the Odyssey before Athena activates him. He has yet to assert himself and "become a man"'. Indeed, Obbink (2014a) goes further, suggesting that Sappho herself fills the Penelope role. In contrast to this equation, the particulars of Odysseus' wish here, with its pointed separation of a wife hopefully 'blameless' and $\varphi$ i $\lambda \circ$ o 'safe and sound', might encourage us to think that the addressee of the Brothers Poem is Sappho's sister-in-law - that is, her older brother Charaxos' wife. If the addressee were the sisterin-law, that might account better for the derogatory tone of $\theta \rho \dot{ }\langle\lambda \eta \sigma \theta \alpha$ in the first stanza; on this model, the goal of the development I tracked in the first part of the paper might then be the merging or collapse of these two distinct categories, wife and $\varphi$ i $\lambda \circ \mathrm{ol}$, into a single harmonious 'we'. On the other hand, the emphasis on Larichos and his saving role for the family still inclines me to think that the addressee is a family member equally invested in both brothers-so again, more likely Sappho's mother than her sister-inlaw. 
But this very obvious epic connection has tended to obscure another mythic model the Brothers Poem seems to me to evoke-and this starts from the imagery of lines $15^{-16}$, 'For periods of fine weather ( $\varepsilon \dot{v} \delta$ í $\alpha$ !) come straightway from great storm blasts'. The imagery of the passing of a storm at sea, significantly applied in this stanza to 'us', reinforces the reciprocal relationship of wished-for safety between Charaxos and those at home I have already suggested. ${ }^{39}$ But simultaneously this imagery sets up for a movement in the last three stanzas that implicitly equates or aligns Sappho's two brothers with the Dioscuri, daimones who save beleaguered ships at sea. To demonstrate the kind of language that tends to be used to describe the saving intervention of the Dioscuri for storm-tossed sailors (both real and metaphorical), I will consider several parallel passages (full Greek texts provided in the Appendix to this chapter): (1) Alcaeus fr. 34, a prayer to the Dioscuri; (2) the longer of the two Homeric Hymns to the Dioscuri (no. 33); (3) two characteristically densely metaphorical passages that frame Pindar's fifth Pythian Ode; and (4) a later adaptation of these same motifs in Theocritus' Hellenistic hymn to the Dioscuri (Idyll 22, lines 14-22). To clarify: I am not claiming specific intertextual links with any of these poems, but rather using the ensemble to build up a set of characteristic themes or motifs associated with the saving action of the Dioscuri at sea. ${ }^{40}$

I will first lay out the parallels, and then consider the application of this mythic model (which may seem prima facie implausible) to Sappho's disparate or asymmetrical brothers. Let me begin with the closest parallel, Pindar's Pythian 5, lines 5-10:

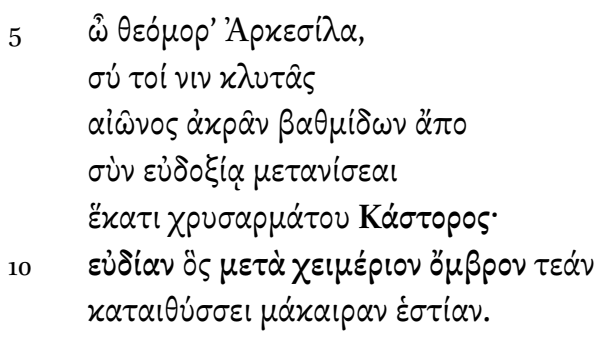

O Arcesilas, favored by heaven, you, to be sure, have been pursuing [wealth] from the earliest steps of your glorious life, together with good

39 Noted also by Nünlist (2014) 14.

40 Thus the dating of Homeric Hymn no. 33 is not an issue for my argument. For discussion of its date relative to Alcaeus fr. 34 , see Page (1955) 267-268, contesting the early (pre-sixth c.) date proposed by Allen, Halliday, and Sikes (1936) 436 . 
repute, thanks to Castor of the golden chariot, who sheds good weather after wintry rain down upon your blessed hearth.

Here, it is Castor who 'sheds evंdiav (fine weather) after wintry rain down upon the blessed hearth' of the victor, Arcesilas, King of Cyrene. ${ }^{41}$ In this context, Pindar is playing on or conflating multiple different associations of Castor, as the divinity who presides over horse and chariot racing (the event in which Arcesilas won his Pythian victory), but who also, together with his brother, offers salvation from storm at sea. ${ }^{42}$ Pindar returns to this latter association at the end of the poem, weaving a complex metaphor within his prayer for the ongoing success and political stability of Arcesilas' reign:

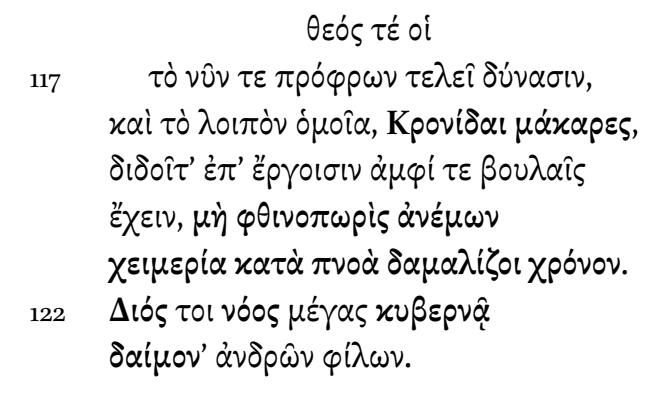

And the god, kindly disposed now, brings his [sc. Arcesilas'] power to fulfillment, and in future, blessed sons of Cronus, may you grant him to have like success upon his works and about his counsels, so that no fruitdestroying stormy blast of winds make havoc of his lifetime. To be sure the great mind of Zeus steers the personal fortune of men who are dear to him.

41 The metaphorical use of $\varepsilon \dot{\delta} \delta i \alpha$ is not that common overall, though it is clearly a favorite image of Pindar's; see Pind. Ol. 1.98, Pyth. 5.10, Isthm. 7.38, frs. 52b.52, 109.1; Aesch. Sept. 795; Soph. Ichneutai 346; Xen. An. 5.8.20; Herondas Mime 1.28. Cf. Obbink (2014b) 43, and especially Stehle's contribution to this volume for extended discussion of the metaphori-

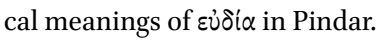

42 At Isthmian 7.38, Poseidon figures in a similar conflation of functions- he is both giver of

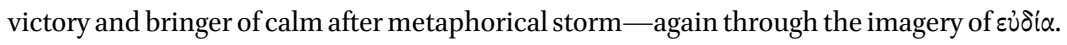
Much of the difference between my interpretation of Sappho's song and that of Stehle's contribution to this volume might be characterized by saying that she regards Isthmian 7

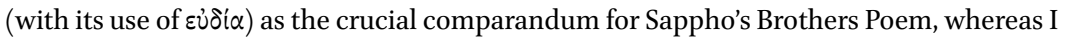

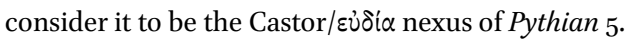


Here the storm from which Castor has saved Arcesilas at the beginning of the ode clearly emerges as the threat of political turbulence, to be fended off by Zeus and his 'blessed' sons, the Dioscuri. (That is to say, I suggest that Pindar's invocation of the Kpoví $\delta \alpha$ $\mu \alpha \dot{x} \alpha$ p $\varepsilon \varsigma$ at line 118 includes not just Zeus, but also his sons, the Dioscuri.) ${ }^{43}$ And I emphasize the political implications of this passage because many scholars likewise read Alcaeus' prayer to the Dioscuri (fr. 34) as a political allegory for the foundering 'ship of state' 44 I would suggest that these same civic, political associations are also relevant for Sappho's artful evocations of the Dioscuri in her Brothers Poem.

But let me return to the Brothers Poem itself, to track its progressive evocation of the saving Dioscuri for Sappho's mortal brothers-and here, we need to be attentive to the precise syntax and connections of thought in the poem. First, there is a striking asyndeton in line 17, at the beginning of the fourth complete stanza. I take this to be explanatory or causal, linking the thought here to the imagery of calm from storm that immediately precedes. ${ }^{45}$ So:

Periods of fine weather straightway come from great blasts of wind. Since of whomever the king of Olympus wishes a daimon as helper now to turn [them] round from toils, those men become happy and richly blessed.

The notion of a daimon sent by Zeus to be a 'helper' for men, who changes the weather from storm to calm, almost inevitably, I think, conjures up the Dioscuri. And this association helps explain the rare and striking word Sappho

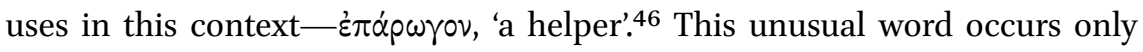
once in all of Homer, used by the shade of Achilles in the Nekuia of Odyssey

43 Note also $x$ $\beta \varepsilon p v \alpha \hat{\mathrm{a}}$, which continues the maritime imagery and connects it with Zeus' particular favor to 'men who are dear' ( $\dot{\alpha} \delta \hat{\delta} \omega \hat{\omega} \nu \varphi \hat{i} \lambda \omega \nu)$ in the final lines of the ode. For the 'ship of state' in general in Alcaeus, see Page (1955) 179-197; for the extension of this allegorical interpretation to Alcaeus fr. 34, see Campbell (1982b) 289, Burnett (1983) 129, Robbins (2013) 248-249.

Cf. Obbink (2014b) 44, who notes the asyndeton, observing that such asyndeton is 'uncommon' in Sappho. For 'explanatory asyndeton', see Kühner and Gerth (1904) II.2 344345. In contrast, such explanatory asyndeton is not infrequent in Pindar's 'austere style': see (for example) Pyth. 3.110-112, Pyth. 6.29, Nem. 3.44-46, Nem. 7.48-50. On asyndeton between propositions in Pindar, see Hummel (1993) 368-376; for explanatory asyndeton in particular, ibid. 372 . Hummel also notes that asyndeton frequently occurs at the beginning of a triad or a strophe (375).

46 This is the correction by a second hand on the papyrus of ह̇ $\pi \alpha p^{\prime} \gamma o v^{\prime}$, although the $\eta$ is not crossed out; see Obbink (2014b) 44. 
Book 11 to bemoan the fact that his father Peleus lives bereft, without a 'helper' such as he himself was when alive (Od.11.494-500; ż $\pi \alpha \omega$ pós at 11.498). Thus in its single Homeric occurrence, the 'helper' is son to the father. $\dot{\varepsilon} \chi \pi \dot{v} v \omega v$ in line 14 of the Brothers Poem also resonates strongly with language associated

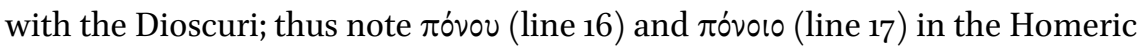
Hymn to the Dioscuri (no. 33) ${ }^{47}$

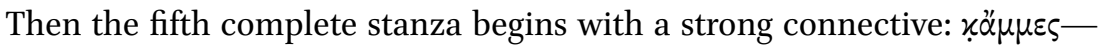
that is, $x a i$ a $\mu \mu \varepsilon \varsigma$. This $x \alpha i$ links the general proposition of the previous stanza to 'our' specific situation, so we might slightly over-translate, 'just so for us'.48 In this last strophe of the poem, as the poet develops the parallel between general and specific, it emerges that it is Larichos himself who will be the savior, who by 'raising his head' will release 'us' from 'many $\beta \alpha p v \theta u \mu$ ial' that are like a storm at sea. The parallelism between the many 'heavinesses of spirit' from which we 'would be released' and the calm after storm of lines $15^{-16}$ is underscored by their occupying the same position in the third and fifth complete stanzas, a responsion made even more conspicuous by the repetition of $\alpha i \psi \alpha$ ('straightway') in exactly the same metrical sedes in each stanza.

Finally, it is worth noting that the last stanza is all about vertical movement, up vs. down. If Larichos should raise his head, we would be released from the heavinesses of spirit that drag us down. ${ }^{49}$ Intriguingly, this same emphasis on up vs. down motion characterizes the saving epiphanies of the Dioscuri in both Homeric Hymn 33 and in Alcaeus fr. 34. Thus in the former, lines 10-13 register that even the highest point of the stern — the poop deck—is ominously 'under

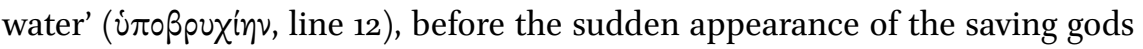
'rushing through the upper air on swift wings' (line 13). In like manner, Alcaeus'

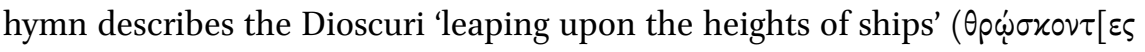

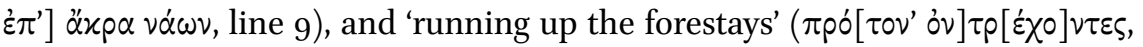
line 10). We might also note the emphasis in both descriptions on the speed and

47 There may be a textual corruption in $\pi$ óvov in line 16 of the Homeric Hymn, but $\pi$ óvo10 in the next line is secure; see Allen, Halliday, and Sikes (1936) 442. Cf. Obbink (2014b) 44 on

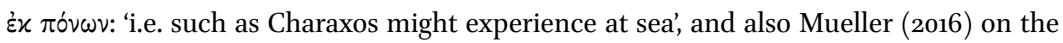
poetics of $\dot{\varepsilon} x$ and $\dot{v} \pi \dot{\varepsilon} x$ here.

48 Cf. West (2014) 9: 'In the closing stanza the general adage is applied to the present circumstances. "So we too, if Larichos will hold his head up and finally behave like a man, might soon find release from our hearts' heavinesses, however many"' (emphasis added). Thanks to Richard Neer for this point. For the same imagery of 'raising the head' in a context of storm at sea, see Soph. OT 22-24 (cited as a comparandum by M.L. West apud Obbink [2014b] 45). 
suddenness of the Dioscuri's saving interventions. Thus (just to focus on the

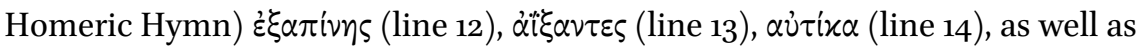
the 'swift horses' the Dioscuri ride in the hymn's final envoi (line 18). We find this same emphasis on sudden transformation together with up-and-down motion in the repeated $\alpha i \psi \alpha$ of the Brothers Poem.

We might note how artfully the implicit pattern of Sappho's two brothers as the saving Dioscuri emerges as the poem progresses, starting to form first with the nautical adage of lines $15^{-16}$ and crystallizing only with the very last stanza in what is a veritable epiphany of Larichos raising his head and becoming a man..$^{50}$ Implicitly Sappho conjures up a vision or after-image of two different or asymmetrical brothers whose mutual $\chi \alpha$ ṕ ı and cooperation will make both immortal. ${ }^{51}$

50 In relation to this veritable epiphany of Larichos at the end of the poem, cf. Morgan this volume, who suggests significant echoes of the Brothers Poem in the second half of Horace Odes 3.29. Note especially the last two strophes of Horace's ode, which introduce the imagery of storm at sea and end with the sudden epiphany of 'twin Pollux' saving the ego amidst 'Aegean storms':

non est meum, si mugiat Africis

malus procellis, ad miseras preces

decurrere et votis pacisci,

ne Cypriae Tyriaeque merces

addant avaro divitias mari:

tunc me biremis praesidio scaphae

tutum per Aegaeos tumultus

aura feret geminusque Pollux.

If Morgan is correct in seeing echoes of our song in Horace Odes 3.29, the ending of the latter suggests that Horace might have recognized an evocation of the Dioscuri as saviors from storm at sea in the last two strophes of Sappho's song.

For $\chi \dot{\alpha}$ pı $\varsigma$ and shared immortality as powerful motifs of the Dioscuri legend, cf. Pindar Nem. 10. And on the weird collapse of mortal and immortal brothers in our poem, cf. Obbink (2014b) 44, who notes that the words $\mu \dot{\alpha} x \alpha \rho$ and $\pi 0 \lambda \dot{0} 0 \lambda \beta 0 \varsigma$ in Sappho most commonly refer to divinities (for $\pi 0 \lambda \dot{0} 0 \lambda \beta \circ \varsigma$, see Sappho fr. 133.2). So here he notes of lines 15-16: 'In the present case a collapse of the distinctions [between human and divine] is anticipated'. See also Robbins (2011) 240-242, 250 on the Dioscuri as generally close to men and on Pindar's Olympian 3 as another poem where we find a doubling of the divine brothers with the human brothers Theron and Xenocrates as hosts of the Dioscuri at a Theoxeny in Acragas. 
If this argument about the evocation or implicit identification of Sappho's brothers with the saving Dioscuri is accepted, it has several significant implications for our reading. First, such a subliminal identification would help explain and justify the somewhat awkward syntax and confusing imagery of the song's fourth complete stanza. M.L. West goes so far as to emend the papyrus' $\dot{\pi} \pi \alpha \eta^{\prime}-$

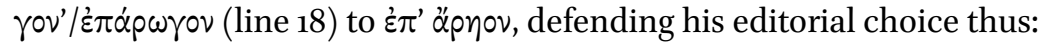

In 14 [18] the papyrus has $\varepsilon \pi \alpha p \eta \gamma \gamma v$, with an omega written above the eta:

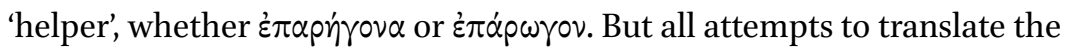
clause with this reading have inevitably been tortured and strained. As Obbink makes it, 'Of whomsoever the King of Olympus wishes a divinity as helper now to turn them from troubles', and he glosses $x$ ivvo as 'those mortals assigned a special guardian divinity by Zeus'. My emendation to ¿̇ $\pi^{\prime}$ äp $\tau \hat{\omega} \nu$ then depends on $\delta \alpha i \mu o v \alpha$, which is used in the sense of 'their fortune'. This, not they, is what is 'turned around', and it is Zeus himself who does it, he does not delegate it to a lesser deity. 'Those whose fortune the ruler of Olympus chooses to turn around from hardship for the better, they come out blessed and prosperous.' 52

Other scholars likewise have objected to these lines' tortured syntax and a theology that strikes some as weirdly Neo-Platonic, with its hierarchy of different levels of gods and daimones. ${ }^{53} \dot{\varepsilon} \pi$ ' $\alpha$ pn does so at the cost of eliding the vivid and consistent imagery of the second half of the poem, which progressively conjures for 'us' at home the threat of storm at

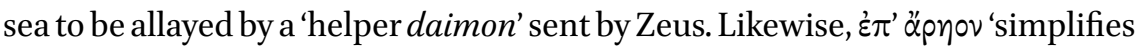
the theology', as West notes, but not necessarily correctly. For in fact, there is nothing strange or 'Neo-Platonic' about the hierarchy of divinities here evoked; that they are 'sent by Zeus', and subject to the will of Zeus and the greater gods is another traditional element of the Dioscuri myth. Thus in addition to their close identification with Zeus in Homeric Hymns 17 and 33, and at the end of Pindar's fifth Pythian ode (cited above, p. 253), we might consider the epiphany

52 West (2014) 9, followed closely by Ferrari (2014) 2-3. See Obbink (2015b) 6 for other arguments against West's emendation, the most significant of which is an echo of the Brothers Poem in Theocritus Idyll 17, lines 123-132, detected originally by Albert Henrichs (apud Obbink).

53 Benjamin Acosta-Hughes ( per litteras); Lardinois (2014) 190 alternatively suggests a parallel with the daimones who are 'watchers from Zeus' in Hesiod $O p$. 122-126. 
of the Dioscuri that closes Euripides' Helen.${ }^{54}$ In Euripides' play, the chorus of Greek slave women call upon the Dioscuri to come as 'saviors of Helen' at the end of their last choral ode (Hel. 1495-1505):

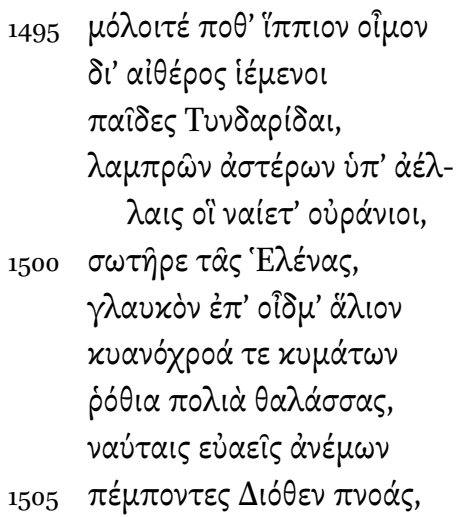

May you come at some time along your horsey path, rushing through the upper air, sons, Tyndaridai, you who inhabit the heavens under the whirling motions of the bright stars, saviors of Helen, over the grey salt swell and the dark-blue and white breakers of the waves of the sea, sending for sailors favorable blasts of winds from Zeus,

This miniature inset hymn to the Dioscuri includes several topoi we have already noted - it registers the brothers' speed, the calming of storm at sea, and (thereby) their saving of beleaguered sailors. What Euripides' hymn crucially adds is that it is Zeus who works through his sons; this is the force of the climactic $\Delta$ Ió$^{\prime} \varepsilon v$ in line 1505 .

Then, when the Dioscuri finally appear as dei ex machina (as if in response to the chorus' summons), Castor(?) pauses to explain the lateness of their intervention (Hel.1658-1661):

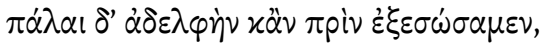

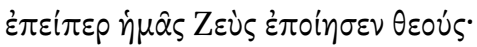

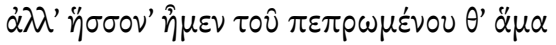

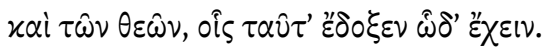

54 Thanks to Mario Telò for calling my attention to the Dioscuri at the end of Euripides' Helen. 
And long before now we would have saved our sister, since Zeus made us gods. But we were weaker than fate and the gods, who wanted these things this way.

As William Allan notes, it is not uncommon for a Euripidean deus ex machina to offer some excuse for his/her non-intervention, but here Euripides seems to be exploiting — and therefore unpacking — a traditional element of Dioscuri theology to do so. ${ }^{55}$

But it might be objected that the Dioscuri model does not in fact fit Sappho's two brothers, since only Larichos is represented as a savior within the song, whereas Charaxos, suspended in the limbo of a sea voyage, is himself potentially in need of saving intervention. And of course it is noteworthy that the 'helper daimon' sent by Zeus in line 18 of the Brothers Poem is singular. But here I get back to the Dioscuri as disparate or asymmetrical brothers. By that I mean to reference first and foremost the fact that Castor and Polydeuces have different fathers and therefore (at least originally) different fates—one originally a son of Zeus and immortal; the other a son of Tyndareus and mortal. In fact, Pindar's Nemean 10 shows us Polydeuces (the immortal one) as savior first and foremost of his own mortal brother Castor, in a narrative that includes many of the elements of what I have identified as 'Dioscuri theology'. Thus Polydeuces comes at great speed ( $\tau \alpha \chi \dot{\varepsilon} \omega \varsigma$, Nem. 10.73) to his mortally wounded brother and saves him through the special dispensation of 'father' Zeus (Nem. 10.73-90). We might even see an extreme version of the Dioscuri's characteristic up-anddown motion in Pindar's repeated references, framing the mythic narrative of Nemean 10, to their shared split immortality, since for Pindar this is all about the regular alternation of locations - 'underneath the earth' and 'in the golden

55 For excuses for non-intervention offered by Euripidean dei ex machina, see Allan (2008) 341, citing parallels. The language of Euripides' Hec. 159-164 also supports the argument

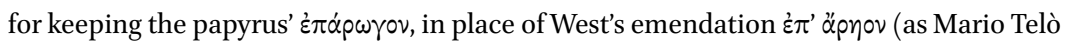
points out to me). For here, precisely in the context of bemoaning the fact that she has lost all her family ('husband' and 'children', lines 159-161), Hecuba cries out in despair,

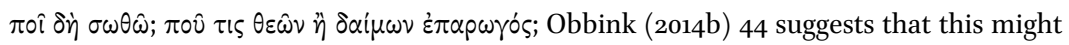
be a deliberate echo of the Brothers Poem, but even if we assume that $\tau \varsigma \theta_{\varepsilon \hat{\omega} \nu} \hat{\eta} \delta \alpha i \mu \omega \nu$

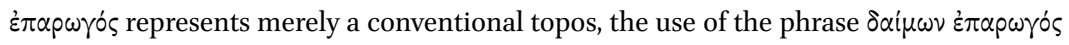
by a mother in the context of a threat to or loss of her children is very suggestive. Note that earlier in the play, Hecuba had referred to Polydorus, whom she believes to be her sole surviving son, as 'the only anchor of my house' (lines 79-80), and that when they bring the news of the planned sacrifice of Polyxena, the chorus of Trojan slave women urge Hecuba, 'but go to the temples, go to the altars' (line 144) to pray for her salvation. 
halls of heaven' (Nem.10.84-88; cf. 55-58). And lest we regard all these elements as Pindar's invention, Proclus' summary of the Cypria shows that this story was traditional..$^{56}$ If we apply this primal scene of salvation to Sappho's Brothers Poem, it suggests that one brother (Larichos) can choose to act in such a way as to make both brothers $\mu \alpha \dot{x} \alpha \rho \varepsilon \varepsilon \varsigma$ and $\pi 0 \lambda \nu$ o $\lambda \beta 0 l$. As for the reference to a singular daimon in the Brothers Poem line 18, it is a striking feature of the Dioscuri in Pindar's rendering that they are an inseparable pair, and yet one can stand in for both (as Castor does in Pythian 5). ${ }^{57}$

Other implications of the Dioscuri paradigm must remain more speculative, since we lack the broader context of what André Lardinois suggests might be a whole 'song cycle' on Sappho's brothers and family life. ${ }^{58}$ Here I would simply note that the Dioscuri model is a flexible one that could accommodate different constructions of Charaxos and Larichos and the speaker's relation to them. Thus, if we follow Dirk Obbink's suggested reading that Charaxos is characterized negatively as a commercial trader in contrast to the positive valuation of Larichos as (potentially) a fully-engaged political actor, ${ }^{59}$ this opposition could be mapped onto the original asymmetry of the Dioscuri which I have already noted. Alternatively, if we follow Richard Martin's suggestion that we should read the newest Sappho as an example of her 'iambic' mode, deftly skewering both brothers within the ostensible frame of a wish for nostos and prayer, we might say that the hovering after-image of the Dioscuri sharpens the blame for both under-achieving human brothers by contrast. ${ }^{60}$

Finally - and most speculatively — if the poem hints at an identification of Charaxos and Larichos with the Dioscuri, it thereby also aligns the ego with their sister Helen. ${ }^{61}$ This implicit identification could also play out in different

56 For the Cypria version, see Proclus Chrest. 80 Severyns (= p. 40 Bernabé). Note that even in this brief summary, we have all the same elements of a cattle raid by Castor and Polydeuces; Idas killing Castor; Polydeuces killing Idas and Lynceus; and finally,

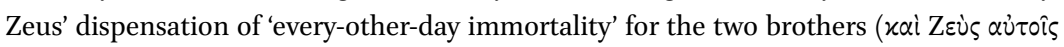

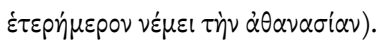

57 Cf. again the last line of Horace Odes 3.29, aura ... geminusque Pollux, where, as Nisbet and Rudd (2004) 364 note, Horace's 'brachylogy' implies Castor as well as Pollux without naming him.

$5^{8}$ Lardinois (2014) 192, 194 and in the present volume.

59 Thus Obbink in his talk at Berkeley in September 2014.

6o See Martin's contribution to this volume; for Sappho's iambic mode, see also Rosenmeyer (2006).

61 Scholars have detected an alignment or identification of the poetic ego with Helen in other Sapphic compositions - most obviously Sappho fr. 16. For this alignment, see duBois (1984), Winkler (1990b) 176-178. 
ways, depending on the broader narrative of which our poem forms a part. Of course in both Iliad and Odyssey, Helen functions as a poet figure, so that the alignment of the ego with Helen is particularly apt. ${ }^{62}$ But otherwise we might feel that the different tonality of Iliadic and Odyssean Helens would significantly change and inflect our readings of the Brothers Poem. If we imagine the more comic Odyssean Helen behind our poem, she provides a point of intersection for the two different aspects or spheres I identified at the outset. By this I mean to capture two aspects of Helen in the Odyssey. First, within the domestic setting of Sparta, she twice preempts Menelaus' speech with her own authoritative utterance, essentially teaching him what he should say in significant contexts. ${ }^{63}$ Second, Helen functions here as a seer figure, a powerful mediator between divine and human spheres and skilled reader of divine signs. ${ }^{64}$ In the former role, Helen furnishes an epic model for the $\theta \rho \dot{ } \lambda^{\lambda} \eta \sigma \theta \alpha-$ $x_{\varepsilon}^{\prime} \lambda \varepsilon \sigma \theta \alpha$ l... $\lambda i \sigma \sigma \varepsilon \sigma \theta \alpha$ l dynamic of our poem, ${ }^{65}$ while in the latter capacity, she might be said to model the way the ego of our poem reaches out in prayer through Hera to Zeus, 'King of Olympus', and to his 'helper' daimon. Alternatively, we might imagine the speaker of the Brothers Poem in relation to the more somber Helen of the Iliad, longing in the Teichoskopia to see her two brothers before her on the plain of Troy, poignantly unaware that they are already dead and buried far away. ${ }^{66}$

Even allowing for these contrasting tonalities, the epic Helen is a powerful figure who effortlessly slips between and mediates different spheresdomestic and public, male and female, human and divine. As such, she offers

62 See Il. 3.125-128 (Helen weaves a figured robe that doubles the Iliad narrative); Od. 4.235264 (Helen tells a story that doubles the Odyssey narrative), 4.277-289 (Helen's uncanny mimetic abilities, imitating the voices of the wives of all the Greek warriors hidden in the wooden horse). There is of course a vast literature on the Homeric Helen as a poet figure; for excellent early discussions of these aspects in both the Iliad and the Odyssey, see the essays collected in Bergren (2008) 43-57 and 111-130.

63 See $O d .4 .116-122,137-154$, where Helen jumps in to identify Telemachus while Menelaus is pondering what to say, and $O d$. $15.166-178$, where, after Peisistratus specifically asks Menelaus to adjudicate the target audience for a bird omen, Helen 'anticipates him, speaking a $\mu \hat{v} \theta 0 \varsigma^{\prime}$ (15.171).

64 See $\mathrm{Od}$. 15.172-178, Helen's authoritative (and entirely accurate) interpretation of a bird omen.

65 Though admittedly, within the exquisitely maintained decorum of epic/Sparta, Helen is always unfailingly polite to her ineffectual husband as she jumps in to speak for him (so no $\theta p \dot{\lambda} \lambda \eta \sigma \theta \alpha$ moment). Cf. Od. 4.263-264, where Helen ends her tale of Odysseus by graciously noting that Menelaus as husband 'lacks nothing, either in wits (phrenas) or in form'.

66 See Il.3.234-244, with thanks to Richard Martin for this suggestion. 
an effective model for the ego as speaker of our song, with her protean and elusive verbal skills interweaving or fusing the poem's disparate spheres. ${ }^{67}$

\section{Appendix (Dioscuri Passages)}

\section{Alcaeus Fr. 34}

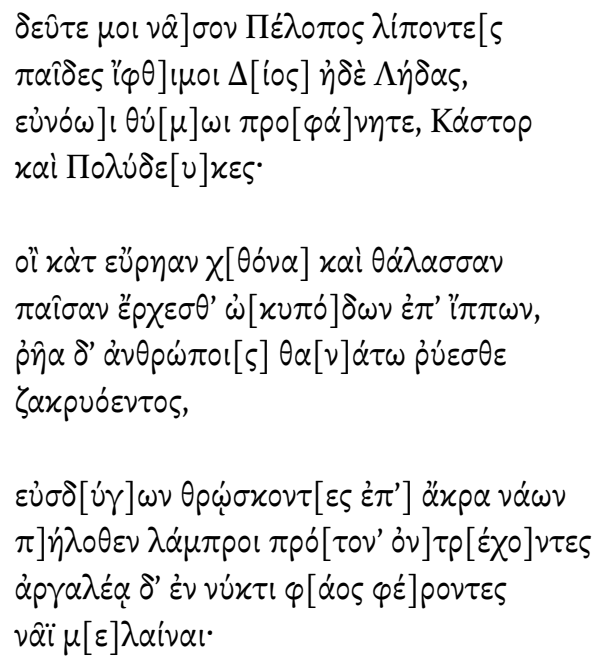

Here for me, having left the Peloponnese, mighty sons of Zeus and Leda, appear with kindly heart, Castor and Polydeuces, you who go over the broad earth and the entire sea on your swift horses, and easily save men from chilly death, leaping on the heights of their well-benched ships, bright from afar as you run up the fore-stays, bringing light in grievous night to a black ship;

67 Thus the Brothers Poem offers us a remarkable and largely unexpected new view of the range of Sapphic poetics. In its abrupt shifts of tonality, juxtaposition of different spheres represented, and complex genre amalgam, all in the service of conjuring a fragmented 'storyworld' of 'everyday life', the Brothers Poem exhibits forms of artistry we had thought distinctive to Latin poets like Catullus, Horace, and Propertius. For the complex narrative effects produced by these poets, I have been particularly inspired by McCarthy (2010) and (2013). 


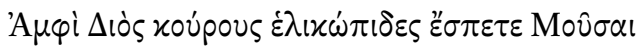

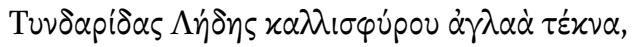

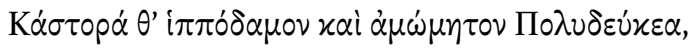

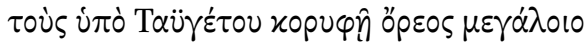

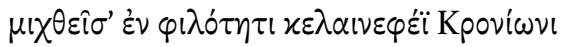

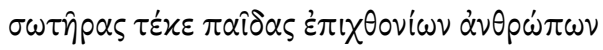

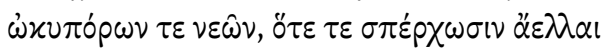

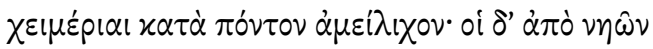

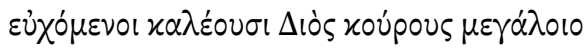

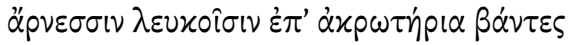

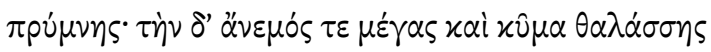

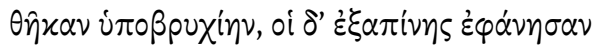

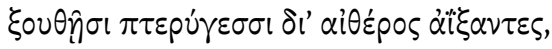

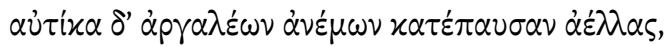

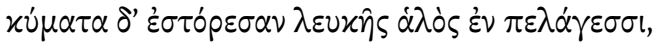

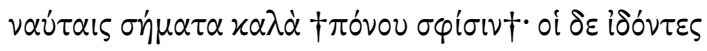

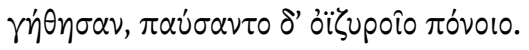

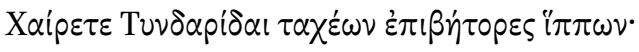

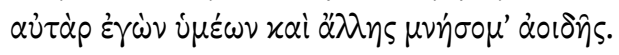

Whirling-eyed Muses, tell about the Tyndarid sons of Zeus, shining children of lovely-ankled Leda, horse-breaking Castor and blameless Polydeuces, the sons whom she bore under the peak of the great mountain Taygetos when she had been mixed in love with the black-clouded son of Cronus, as saviors of men upon the earth and of swift ships, when wintry stormblasts rush over an unfriendly sea. But they, praying from ships, call upon the sons of great Zeus with [sacrifice of] white lambs, when they have gone up to the poop-deck. But it [the stern] both great wind and the swell of the sea have caused to be submerged. But they [sc. the Dioscuri] suddenly appear, rushing through the air on swift wings. And immediately they stop the blasts of grievous winds and they smooth out the swells of white salt water on the plains of the sea, as noble signs of toil(?) for sailors; but they [sc. the sailors] rejoice when they see [them], and they cease from grievous toil. Hail Tyndaridai, riders of swift horses! But I will remember you and another song. 


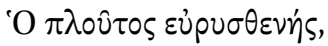

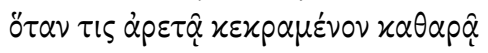

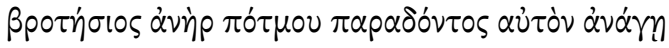

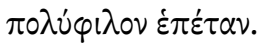

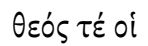

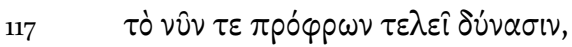

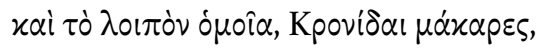

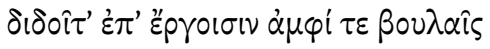

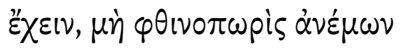

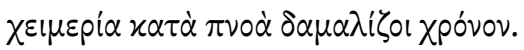

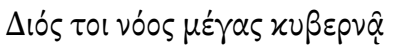

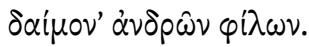

Wealth is broad in strength, whenever any mortal man leads it forth mixed with pure excellence, when fate has transmitted it to him as an attendant that has many friends. O Arcesilas, favored by heaven, you, to be sure, have been pursuing it from the earliest steps of your glorious life, together with good repute, thanks to Castor of the golden chariot, who sheds good weather after wintry storm down upon your blessed hearth.

And the god, kindly disposed now, brings his [sc. Arcesilas'] power to fulfillment, and in future, blessed sons of Cronus, may you grant him to have like success upon his works and about his counsels, so that no fruitdestroying stormy blast of winds make havoc of his lifetime. To be sure the great mind of Zeus steers the personal fortune of men who are dear to him. 


\section{4} Theocritus Idyll 22, Lines 14-22

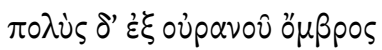

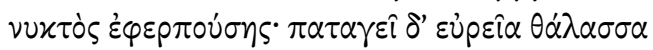

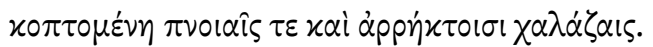

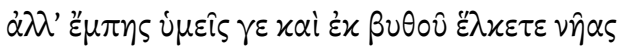

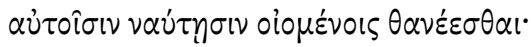
$\alpha i \psi \alpha \alpha \delta^{\prime} \dot{\alpha} \pi 0 \lambda \eta^{\prime} \gamma \sigma v \sigma^{\prime} \alpha \dot{\alpha} v \varepsilon \mu 01, \lambda ı \pi \alpha \rho \eta \dot{~} \delta \dot{\varepsilon} \gamma \alpha \lambda \eta^{\prime} \nu \eta$

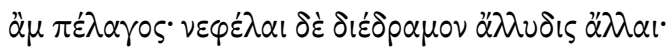

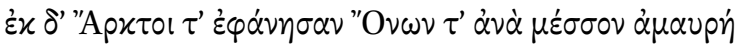

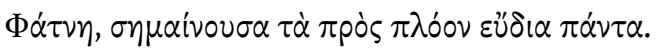

And there is much rain from heaven as the night comes on, and the broad sea roars as it is struck by blasts of wind and relentless hails. But still you [sc. the Dioscuri] drag ships even from the depth [of the sea], together with their sailors, who think they will die. And straightway the winds cease, and there is bright calm upon the plain of the sea, and the clouds scatter in different directions here and there. And the Bears appear, and in the middle of the Asses the dim Manger, signifying that all is good weather for sailing. 